\title{
Response and Resistance Mechanism of Shallot Var. Topo, a North Molluca's Local Variety Against Basal Rot Disease
}

\author{
Hermawati Cahyaningrum ${ }^{1, *}$, Suryanti ${ }^{2}$, Ani Widiastuti ${ }^{2}$ \\ ${ }^{I}$ Assessment Institute for Agriculture Technology North Maluku, Tidore, Indonesia \\ ${ }^{2}$ Faculty of Agriculture, Universitas Gadjah Mada, Yogyakarta, Indonesia \\ "Corresponding author.Email: aniwidiastuti@ugm.ac.id
}

\begin{abstract}
Shallots especially Topo shallot cultivar was one of the strategic horticulture commodities which had high economical valued for farmer in North Molluca. Cultivation of shallot is mostly contrained bt basal rot disease caused by fungus Fusarium spp. complex. The aim of study is to determine Topo shallots response and it's resistance to basal rot disease. The research using Topo shallots with comparative cultivars of Biru, Tiron, and Lembah Palu. The results showed that Topo shallots centrally location at Trans Koli SP - 1, Tidore Kepulauan Regency and Tutuling Jaya, East Halmahera Regency showed the basal rot disease symptoms which is being twisted, pale and yellowing. The disease incidence and disease intensity were $61,75 \%$ and $77,50 \%$ in Trans Koli SP - 1, while in Tutuling awa were $62,09 \%$ and $70 \%$. Resistance tests showed that disease incident of Blue, Tiron, Lembah Palu and Topo were 74,40\%, 64,80\%, $77 \%$ and 65\%, respectively. The resistance level of Topo is not better than Biru, Tiron, and Lembah Palu. The response of Topo's shallots resistance against basal rot disease is seen through the accumulation of lignin in the shallots plate.
\end{abstract}

Keywords: Topo shallots, basal rot disease, lignification, shallot

\section{INTRODUCTION}

Shallot is one of the leading commodity horticulture in Indonesia which has long been intensively cultivated by farmers. The selling price of shallots is quite high in the market, therefore the integrity and number of requests tends to increase in line with the increase in population and increase in people's purchasing power. Problems with onion farming include basal rot disease or twisted disease disorders [1]. Basal rot disease is caused by the fungus Fusarium spp. complex. State that twisted disease causes symptoms of wilting, root rot and leaf winding [2]. The symptoms of wilting are caused by $F$. solani and $F$. acutatum, root rot caused by $F$. solani, $F$. acutaum or $F$. oxysporum, while the leaves are curved due to $F$. solani or $F$. acutatum. Symptoms of the disease that appear are the leaves dry and sway (twisting) starting from the top because the tubers rot. In addition to the upper part of the plant, this disease can also occur in the bulbs of the crop yield in storage [3].

Interactions between plants and pathogens produce infectious reactions or resistance reactions [4]. One response to the response of plant resistance to pathogens is the presence of structural barriers as physical barriers that will inhibit pathogen infections. This barrier structure includes a layer of wax, warts, suberin, lignin, polysaccharides, cell walls and cell wall glycoproteins [5]. Lignin can strengthen special cell walls and play an important role in plant resistance to disease [6].
Tidore Island in North Maluku Province has a wealth of local onion germplasm named Bawang Topo. Bawang Topo has been registered at the Center for Plant Variety Protection with a list with a category of local varieties Number: 232 / PLV / 2016 established on December 27, 2016. Information about Topo Onions is still limited to opinions and public opinion that are subjective so that their advantages and disadvantages have not well documented. The purpose of this study was to determine the response of Bawang Topo to basal rot disease and it's resistance mechanism.

\section{METHODS}

Observation of basal rot disease in the field

Observation of symptoms in the field was carried out by a survey method in the shallots field in North Maluku, namely Trans Koli-SP1, Tidore Kepulauan Regency and Tutuling Jaya, East Halmahera Regency. A field survey was conducted to see the incidence and intensity of basal rot disease in the field.

\section{Preparation of inoculum}

The isolate used was $F$. acutatum isolate obtained from the collection of the Laboratory of Plant Clinical Faculty of Agriculture, Universitas Gadjah Mada, Yogyakarta. Mycelium from the isolate collection was transferred into PDA media then incubated within $5-7$ days. The conidium released from the media using a brush calculated its population by the dilution method. The conidia 
concentration was calculated using a hemasitometer to get the concentration of $10^{6}$ conidia $/ \mathrm{ml}$

\section{Testing the response of plants to $\underline{F \text {. acutatum }}$}

Shallot used were from Topo from Tidore (North Maluku), Bima and Tiron from Bantul and Sleman (Yogyakarta), and Lembah Palu from Palu (Central Sulawesi). Shallot bulb were disinfected by soaking in a $1 \%$ Na-hypochlorite solution for about 30 minutes then rinsing with sterile water. Planting was carried out on sterile soil media that had been watered with $50 \mathrm{ml}$ of conidia suspense in a greenhouse [2].

The incubation period is calculated from inoculation until the first symptoms appear in units of days after inoculation (hsi). Symptoms of the disease are observed once a week together with observations of the disease incidence and disease severity. The disease license is calculated using the formula:

$$
\text { DI }(\%)=\frac{n}{N} \times 100 \%
$$

Notes:

DI $=$ disease incidence

$\mathrm{n} \quad=$ number of diseased plants

$\mathrm{N}=$ total number of plants

The disease severity was calculated using scoring. The scoring values used are: $0=$ no symptoms of attack, $1=0$ $20 \%$ of leaves attacked, $2=21-40 \%$ of leaves attacked, $3=$ $41-60 \%$ of leaves attacked, $4=61-80 \%$ of leaves attacked, $5=81-100 \%$ of the leaves are attacked. Disease severity values are calculated using the formula:

Notes:

$$
\text { DS }(\%)=\frac{\sum(\mathrm{nxv})}{\mathrm{Z} \times \mathrm{N}} \times 100 \%
$$

DS = disese severity

$\mathrm{n}=$ number of plants per attack category,

$\mathrm{v}=$ score of attack category score,

$\mathrm{Z} \quad=$ highest score of attack category score,

$\mathrm{N} \quad=$ number of plants observed.

Criteria for resistance levet to basal rot diseases are Immune ( $0 \%$ disease severity), Resistant ( $1-20 \%$ disease severity), Moderate (21-40\% disease severity), Susceptible $(21-40 \%$ disease severity) and Very Susceptible (disease severity $71-100 \%)$ [8].

The study used a completely randomized design with five replications. Each test consisted of five plants. The data obtained were statistically analyzed using the F Test using the SAS 9.3 program. If in the F Test there are significant differences, the difference between treatments is continued with the Duncan Multiple Range Test (DMRT) at the 5\% level.

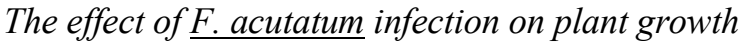

Plant growth was observed once a week, carried out until harvest time. The observation variables were plant height, number of leaves, number of bulb, and bulb weight.

\section{Detection of lignification in shallots bulb}

Lignification was observed by cutting transversely on the portion of an infected shallots bulb by $0.5 \mathrm{~cm}$. Pieces of the bulb are immersed in 1\% Phloroglucinol solution in $96 \%$ alcohol for 15 minutes, then immersed in $10 \% \mathrm{HCl}$ solution for 5 minutes. Transverse slices of the bulb preparation were then observed using a light microscope to see the lignification that appeared in the tissue and carried out documentation.

\section{RESULTS AND DISCUSSION}

\section{Basal rot disease in the field}

Observations have been made on the shallots planting area in the production center, namely in the Trans Koli-SP1, Tidore Kepulauan Regency and Tutuling Jaya, East Halmahera Regency. Shallot plants in both locations were found to have been infected with basal rot disease (Figure $1)$.

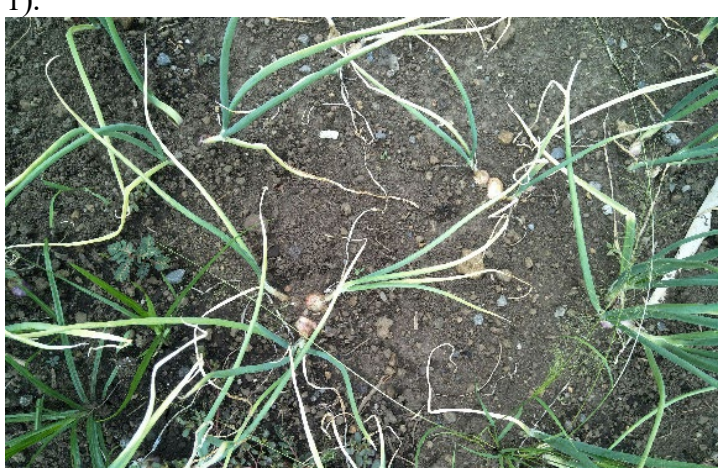

Figure 1. Basal rot disease symptoms in the field

Table 1 shows that there were differences in the incidence and intensity of disease in the two regions observed. Different levels of disease attack can occur due to many factors, including differences in temperature and humidity. Reported that climate factors can directly increase the incidence of basal rot disease in shallots in India [8]. Environmental factors help the development and spread of disease [9]. Furthermore mentions humidity between 85 $96 \%$, temperatures between $20-31{ }^{\circ} \mathrm{C}$ and rain are factors that can help the development and spread of disease [10].

Table 1. Disease incidence and disease severity of basal

\begin{tabular}{|c|c|c|c|c|c|}
\hline Location & $\begin{array}{c}\text { Coordinate } \\
\text { Point }\end{array}$ & $\begin{array}{l}\text { DI } \\
(\%)\end{array}$ & $\begin{array}{l}\text { DS } \\
(\%)\end{array}$ & $\begin{array}{c}\mathrm{T} \\
\left({ }^{\circ} \mathrm{C}\right)\end{array}$ & RH \\
\hline $\begin{array}{l}\text { Trans } \\
\text { Koli-SP } \\
1\end{array}$ & $\begin{array}{c}0^{\circ} 24^{\prime} 28.8^{\prime \prime N} \\
127^{\circ} 43^{\prime} 11.4^{\prime \prime} \mathrm{E}\end{array}$ & 61.75 & 77.50 & $21-35$ & $48-98$ \\
\hline $\begin{array}{l}\text { Tutuling } \\
\text { Jaya }\end{array}$ & $\begin{array}{c}1^{\circ} 11^{\prime} 33.4^{\prime \prime N} \\
128^{\circ} 1327.7^{\prime \prime E} \\
\end{array}$ & 62.09 & 70.00 & $27-28$ & $76-85$ \\
\hline
\end{tabular}
rot disease in Topo shallots in the field

\section{Observed Basal rot disease}

Basal rot disease is caused by the fungus Fusarium spp. complex, one of which is $F$. acutatum. The results of the isolation of pathogens from basal rot disease symptomatic test plants obtained three conidium fungi, namely 
microcondidium, macroconidium, and chlamydispore (Figure 2).

Symptoms of the disease were seen in all the cultivars tested, which were twisted leaves, pale green at the beginning of the attack and then yellowing, the leaves had an abnormal extension, and the bulb rot (Figure 3). These diverse symptoms are similar to the symptoms reported by [2] which states that Fusarium spp. cause various symptoms in shallots, were twisted leaves, yellowing and drying. When the bulb was cut, it showed brown spots. Tuber rot is associated with rapid drying of leaves when plants are pulled out.

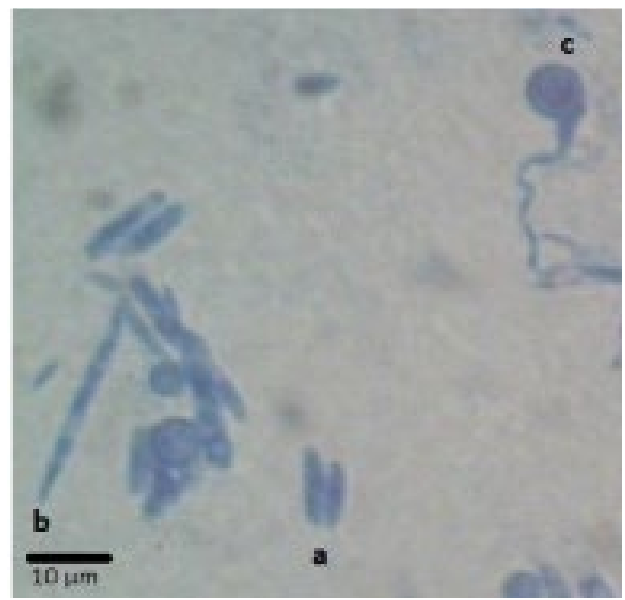

Figure 2. Conidia of F. acutatum (a) microdonidium, (b) macroconidium (c) chlamydiospore

\section{Plant response to fungal infections}

The results showed that the incubation period of basal rot disease in shallots observed in the greenhouse was $7-12$ hsi. The initial symptoms of disease in the field appear at the age of $20 \mathrm{hst}$, while the symptoms will appear after 714 days if the infection is through seedlings and 30 days if the infection is through the ground [11]. The incubation period of the disease in this study is faster, in addition to being influenced by the pathogen and its host, also due to environmental factors namely the temperature range between $24-28{ }^{\circ} \mathrm{C}$ and humidity between $75-100 \%$. These conditions affect the growth and/or susceptibility of the host, the development and activity of pathogens, hostpathogen interactions, and the development of symptoms.

Table 2 shows all shallot cultivars showing symptoms of basal rot disease with a $100 \%$ disease incidence. The highest disease severity was seen in the Lembah Palu cultivar of $77 \%$ followed by Blue of $74.40 \%$, Topo of $65 \%$ and Tiron of $64 \%$. Based on disease severity values, all shallot cultivars tested were susceptible to basal rot disease (disease severity $>50 \%$ ). Blue cultivar and Lembah Palu are said to be very susceptible cultivars, while Tiron and Topo are susceptible to F.acutatum infection. The Tiron cultivar is indicated to be resistant to basal rot disease caused by $F$. oxysporum. The results showed that Tiron was susceptible to basal rot disease caused by $F$. acutatum [12]. This difference shows that plant endurance can one day change depending on the influence of various factors including virulent pathogens, plant growth and environmental conditions. Differences in morphology, physiology and resistance genes of each cultivar also affect the level of plant resistance. The structural characteristics and biochemical reactions of plants affect plants in forming defense systems. States that differences in plant resistance are also influenced by a combination of plant age, type of organ and plant tissue affected, nutrients contained in plants and environmental conditions [13].

Table 2. Plant responses to fungal infections

\begin{tabular}{|l|c|c|c|c|c|}
\hline \multicolumn{1}{|c|}{ Cultivar } & IP (hsi) & DI (\%) & DS (\%) & L & RL \\
\hline Biru & $9,40 \mathrm{bc}$ & $100 \mathrm{a}$ & $74,40 \mathrm{a}$ & + & very susceptible \\
\hline Tiron & $7,80 \mathrm{c}$ & $100 \mathrm{a}$ & $64,80 \mathrm{~b}$ & + & susceptible \\
\hline Lembah Palu & $9,40 \mathrm{bc}$ & $100 \mathrm{a}$ & $77,00 \mathrm{a}$ & + & very susceptible \\
\hline Topo & $12,00 \mathrm{a}$ & $100 \mathrm{a}$ & $65,00 \mathrm{~b}$ & + & susceptible \\
\hline
\end{tabular}
Notes: number followed by the same letter in the same column show
no differences between treatment according to DMRT at a $95 \%$ confidence level.
IP = Incubation Period; DI = Disease Incidence;
DS = Disease Severity; L = Lignification; RL = Resistance Level

\section{Effect of F. acutatum infection o plant growth}

The results showed that the fungus infection of $\mathrm{F}$. acutatum affected the growth of all shallot cultivars tested. In general, pathogenic fungal infections cause local symptoms in the host separately or together also cause reduced growth of plant organs or whole plants [13].

The results of statistical analysis on plant height and number of leaves showed differences between treatments, while the number of bulb and bulb weights were no difference between all cultivars tested. The highest average plant height was found in the Tiron while the lowest plant height was in the Lembah Palu. Topo have the highest number of leaves, number of bulb and bulb weight. Whereas the lowest number was found in Biru cultivars (Table 3).

Inhibition of plant growth in each cultivar is different, depending on the characteristics of each cultivar. In Topo shallots, infection of $F$. acutatum reduce bulb wet weight up to $30.51 \%$ from normal weight, $7.47 \%$ normal bulb number, $26,06 \%$ normal number of leaves and $8.6 \%$ of normal plant height. This results shows that $F$. acutatum infection affects plant growth because the transportation of nutrients and nutrients is inhibited so that it affects plant metabolism that causes plant growth is inhibited. Fusarium sp. caused vascular wilting, grow and develop in xylem 
vessels in infected plants so that it will cause interference with the nutrient transportation system in the host plant tissue [13].

Table 3. lowest number was found in Biru cultivars

\begin{tabular}{|l|c|c|c|c|}
\hline Cultivar & PH (cm) & NL (pcs) & NB (pcs) & BW (g) \\
\hline Biru & $30,26 \mathrm{a}$ & $7,32 \mathrm{a}$ & $4,80 \mathrm{a}$ & $9,60 \mathrm{a}$ \\
\hline Tiron & $33,38 \mathrm{a}$ & $9,24 \mathrm{~b}$ & $5,40 \mathrm{a}$ & $10,80 \mathrm{a}$ \\
\hline $\begin{array}{l}\text { Lembah } \\
\text { Palu }\end{array}$ & $19,34 \mathrm{~b}$ & $7,52 \mathrm{a}$ & $8,00 \mathrm{a}$ & 16,001 \\
\hline Topo & $8,60 \mathrm{bc}$ & $8,60 \mathrm{ab}$ & $8,20 \mathrm{a}$ & $16,40 \mathrm{a}$ \\
\hline
\end{tabular}

Notes: number followed by the same letter in the same column show no differences between treatment according to DMRT at a 95 $\%$ confidence level.

$\mathrm{PH}=$ plants height $; \mathrm{NL}=$ number of leaves; $\mathrm{NB}=$ number of bulb; BW = bulb wet weight

Basal rot disease caused by $F$. oxysporum f.sp cepae can inhibit the growth of shallots [14]. F. oxysporum f.sp cepae colonizes the shallots roots and inhibits the process of transporting water and photosynthate results to all parts of the plant. The production of toxins by the fungus changes the flexibility of the plasma membrane in plants, causing leaves to sway [14]. A high Fusarium fungus level attack causes the bulb wet weight to decrease, and vice versa if the fungus attack rate is low, it is likely not to affect the bulb wet weight [15].

\section{Lignification in tubers discs infected with F. acutatum}

Observations showed that lignin was formed in plants which were inoculated with $F$. acutatum (Table 2). Lignification is indicated by the presence of a purplish red color in the cortical disk tissue of the bulb containing lignin (Figure 3). Lignin appears as a mechanism of resistance to shallots plants infected by $F$. acutatum. Most lignin accumulation was seen in Blue cultivar onion with disease intensity of $74.40 \%$, followed by Tiron $(64.80 \%)$, Topo $(65 \%)$ and Lembah Palu (77\%). Lignin formation in plants is influenced by many factors, including plant age, plant growth stage, genotype, morphology, and environmental factors [16]. The difference in lignin accumulation among test shallot cultivars is due to genetic differences in each plant, as well as the high population of $F$. acutatum inoculums used so as to influence disease severity and plant resistance to pathogen infections.

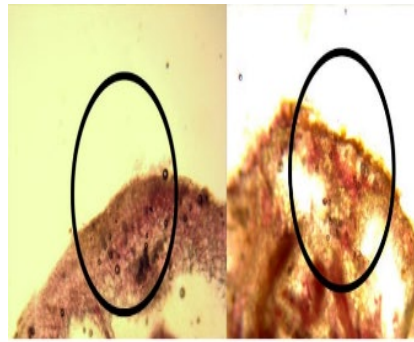

(a) (b)

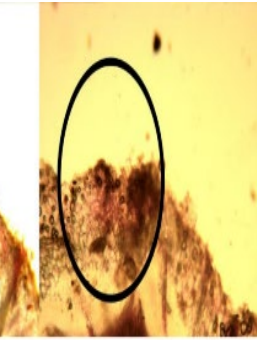

(c)

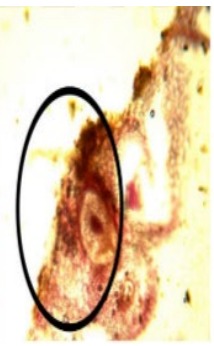

(d)
Figure 3. Lignin accumulation on shallots bulb (a) Biru (b) Tiron (c) Lembah Palu (d) Topo

\section{CONCLUSION}

1. The symptoms of basal rot disease on Topo shallots were twisted leaves, pale green and yellowing leaves, an abnormal extension of leaves, and the tubers rot

2. The resistance level of Topo shallot to basal rot disease was not better than Biru, Tiron and Lembah Palu

3. Lignin was formed in all cultivars tested as a mechanism of plant resistance to $F$. acutatum

\section{ACKNOWLEDGMENT}

The author wish to thank to the Agricultural Research and Development Agency, Ministry of Agriculture of the Republic of Indonesia for funding this research. The research was part of thesis.

\section{REFERENCES}

[1] Sumarni N., dan A. Hidayat, " Budidaya Bawang Merah ", Balai Penelitian Tanaman Sayuran, Pusat Penelitian dan Pengembangan Hortikultura, Badan Penelitian dan Pengembangan Pertanian Bioprospek, Bandung, 2005.

[2] Lestiyani A., A. Wibowo, S. Subandiyah, C. Gambley, S. Ito, S. Harper, "Identification of Fusarium spp., The Causal Agent of Twisted Disease of Shallot", Acta Hortic. Pp. 155 - 160, 2016.

[3] Wibowo A., Aulia R. A., Medina Uli A., Siti S., Tony P., Agustin M., “ Increasing Soil Suppresivity To Fusarium Wil of Banana Through Banana Intercroping With Allium spp., " Jurnal Perlindungan Tanaman Indonesia 19, pp. 33- 39, 2015.

[4] Soesanto L., Ruth F. R., “ Pengimbasan Ketahanan Bibit Pisang Ambon Kuning Terhadap Penyakit Layu Fusarium Dengan Beberapa Jamur Antagonis ", Jurnal Hama dan Penyakit Tumbuhan Tropika 9 (2), pp 130 - 140, 2009.

[5] Siregar E. B. M., “ Pertahanan Metabolik Dan Enzim Litik Dalam Mekanisme Resistensi Tanaman Terhadap Serangan Patogen ", Fakultas Pertanian Universitas Sumatera Utara, Medan, 2003.

[6] Lewis N. G., L. B. Davin, “ Evolution of Lignin And Neolignan Biochemical Pathways ". Evolution of Natural Products? ACS Symposium Series 562, pp. 202 - 246, 1994.

[7] Juwanda M., Khusnul K., Mohamad A., “ Peningkatan Ketahanan Bawang Merah Terhadap Penyakit Layu Fusarium Melalui Induksi Ketahanan Dengan Asam Salisilat Secara In Vitro '. Agrin 20. Pp. 15 - 28, 2016.

[8] Patil S., V. B. Nargund, Santosh R. M., “Influence of Wheater Parameters On Development of Twister Disease of Onion ", The Bioscan 11 (4), pp. $2821-2824,2016$.

[9] Guyota, Omandab. G. N., "Some Epidemiological Investigations on Colletotrichum Leaf Disease On 
Rubber Tree “, J. Crop Protection 24, pp. 65 - 77, 2005.

[10] Weeraratne G. W. A. P. “ Leaf Twister Disease Of Onion (Allium cepa L.), Thai Phytopathol 18, pp. 63-69.

[11] Wiyatiningsih S.," Kajian Asosiasi Phytopththora sp. dan Fusarium oxysporum f. sp cepae Penyebab Penyakit Moler Pada Bawang Merah, 2003.

[12] Wiyatiningsih S., Arif W., Endang T. P., “ Keparahan Penyakit Moler Pada Enam Kultivar Bawang Merah Karena Infeksi Fuarium oxysporum f. sp cepar Di Tia Daerah Sentra Produksi ", Prosiding Seminar Nasional Akselerasi Pengembangan Teknologi Pertanian Dalam Mendukung Revitalisasi Pertanian, 2009.

[13] Agrios G. N, “ Plant Pathology $5^{\text {th }}$ Edition “, Elsevier Academic Press, New York, 2005.

[14] Prakoso, E. B, Sri W., Heri N., “ Uji Ketahanan Berbagai Kultivar Bawang Merah (Allium ascalonicum) Terhadap Infeksi Penyakit Moler (Fusarium oxysporum f.sp cepae) “, Plumula 5 (1), pp. $10-20,2016$.

[15] Supriyadi, A., Ika R., Syamsuddin D., “ Kejadian Penyakit Pada Tanaman Bawang Merah Yang Dibudidayakan Secara Vertikultur Di Sidoarjo ', Juenal HPT 1 (3), pp. 27 - 40, 2013.

[16] Frei M, “ Lignin: Characterization of a Multifaceted Crop Component ", The Scientific World Journal, pp. 1 - 25, 2013. Frei M, “ Lignin: Characterization of a Multifaceted Crop Component “, The Scientific World Journal, pp. 1 $-25,2013$. 